\title{
ANALISIS MARGIN TATANIAGA DAN RISIKO DISTRIBUSI TOMAT DI PASAR TRADISIONAL KOTA BOGOR (PENDEKATAN ENTERPRISE RISK MANAGEMENT)
}

\section{ANALYSIS OF TATANIAGA MARGIN AND TOMATO DISTRIBUTION RISK IN THE TRADITIONAL MARKET OF BOGOR CITY (ENTERPRISE RISK MANAGEMENT APPROACH)}

\author{
S. Afandi ${ }^{1}$, H. Miftah ${ }^{1 \mathrm{a}}$ dan W. Nahraeni ${ }^{1}$ \\ ${ }^{1}$ Jurusan Agribisnis, Fakultas Pertanian, Universitas Djuanda Bogor \\ Jalan Tol Ciawi 1, Kotak Pos 35 Bogor 16720 \\ a'Korespondensi: Himmatul Miftah Telp: 08568049670 E-mail : hmiftah@yahoo.co.id
}

\begin{abstract}
This study aims to analyze trading margins, measure and map distribution risks, and determine the level of trading actors in implementing risk mitigation actions. The research method uses purposive and snowball sampling. Data were analyzed using descriptive analysis through interviews and quantitative analysis through trade analysis and ERM methods. The results show that the biggest margin is at the retail level, the smallest margin at the level of large traders in the retail market. The smallest part of the farmer is in trade channel 1 and the largest on the trade channel 2. The biggest risk is at the retail level, the smallest at the middlemen level. Margin is proportional to the risk at the retail level. Risk mapping consists of a watchful risk: (1) weight loss (2) physically damaged during sorting at the farm level. Risks that rarely occur: (1) weight loss when delivered at the wholesale level at retail, retail, and when selling merchandise at the retail level. Risks that often occur, but have a small impact: (1) weight loss when delivered at middlemen and wholesalers in the retail market, when selling merchandise at the wholesale level at the wholesale market (2) physically damaged when sorting at the wholesale level on the wholesale market, wholesale at retail, retail (3) not sold when selling merchandise at the wholesale level at the wholesale, retail market. Mitigation actions are carried out on: (1) shrinkage of weights carried out at the farmer and middleman level (2) physically damaged at the farm level, wholesalers at wholesale markets, wholesalers at retail, retail markets (3) unsold at wholesalers at wholesale, retail markets.
\end{abstract}

Key Words: ERM, risk, weight loss, physically damaged, mitigation.

\begin{abstract}
ABSTRAK
Penelitian ini bertujuan untuk menganalisis margin tataniaga, pengukuran dan pemetaan risiko distribusi, serta menentukan tingkat pelaku tataniaga dalam menerapkan tindakan mitigasi risiko. Metode penelitian menggunakan purposive dan snowball sampling. Data dianalisis menggunakan analisis deskriptif melalui wawancara dan kuantitatif melalui analisis tataniaga dan metode ERM. Hasil penelitian menunjukkan margin terbesar terdapat di tingkat retail, margin terkecil terdapat di tingkat pedagang besar di pasar retail. Farmer's share terkecil terdapat pada saluran tataniaga 1 dan terbesar pada saluran tataniaga 2. Risiko terbesar terdapat di tingkat retail, terkecil di tingkat tengkulak. Proporsional margin dengan risiko terdapat di tingkat retail. Pemetaan risiko terdiri atas risiko yang diwaspadai : (1) susut bobot (2) rusak fisik saat sortasi di tingkat petani. Risiko yang jarang terjadi : (1) susut bobot saat pengiriman di tingkat pedagang besar di pasar retail, retail, dan saat menjual dagangan di tingkat retail. Risiko yang sering terjadi, namun memiliki dampak yang kecil : (1) susut bobot
\end{abstract}


saat pengiriman di tingkat tengkulak dan pedagang besar di pasar retail, saat menjual dagangan di tingkat pedagang besar di pasar induk (2) rusak fisik saat sortasi di tingkat pedagang besar di pasar induk, pedagang besar di pasar retail, retail (3) tidak terjual saat menjual dagangan di tingkat pedagang besar di pasar induk, retail. Tindakan mitigasi dilakukan pada : (1) susut bobot dilakukan di tingkat petani dan tengkulak (2) rusak fisik di tingkat petani, pedagang besar di pasar induk, pedagang besar di pasar retail, retail (3) tidak terjual di tingkat pedagang besar di pasar induk, retail.

Kata Kunci : ERM, risiko, susut bobot, rusak fisik, mitigasi.

\section{PENDAHULUAN}

Produk Domestik Bruto (PDB) atas harga berlaku di Indonesia pada tahun 2016 sampai 2018 ditunjang oleh beberapa lapangan usaha salah satunya adalah sektor pertanian. Sektor pertanian menjadi sektor penyumbang PDB terbesar kedua di Indonesia setelah sektor industri dan pengolahan. Menurut data Badan Pusat Statistik (BPS) tahun 2018, PDB sektor pertanian mengalami peningkatan yang berfluktuasi setiap tahunnya. Tahun 2016 tercatat sebesar Rp. 1.671.330,30 dan meningkat sebesar $6,4 \%$ pada tahun 2017 , kemudian mengalami penurunan sebesar $16,8 \%$ pada tahun 2018 .
Kota Bogor merupakan salah satu kota di Jawa Barat dengan hasil produksi tomat yang lebih tinggi jika dibandingkan dengan hasil produksi komoditas sayuran lainnya. Hasil produksi tomat di Kota Bogor pada tahun 2016 sebesar 1.276 ton (BPS Kota Bogor, 2017).

Hasil produksi tomat di Kota Bogor pada umumnya didistribusikan ke pasar tradisional Kota Bogor khususnya Pasar Baru Bogor dan Pasar Jambu Dua. Pasar tersebut menjadi pasar tradisional terluas di Kota Bogor dengan komoditas utama yang diperjualbelikan adalah sayuran seperti tomat.

Tabel 1 PDB Atas Harga Berlaku di Indonesia Tahun 2016-2018

\begin{tabular}{lrrr}
\hline \multirow{2}{*}{ Jenis Lapangan Usaha } & \multicolumn{3}{c}{ Tahun (Miliar Rupiah/Tahun) } \\
\cline { 2 - 4 } & $2016^{*}$ & $2017 * *$ & $2018^{* * *}$ \\
\hline Pertanian, Kehutanan, dan & $1.671 .330,30$ & $1.785 .880,70$ & $1.485 .961,40$ \\
Perikanan & & & \\
Pertambangan dan Penggalian & $890.868,30$ & $1.028 .772,20$ & $885.838,20$ \\
Industri dan Pengolahan & $2.545 .203,50$ & $2.739 .415,00$ & $2.194 .029,10$ \\
Lainnya & $7.299 .372,00$ & $8.034 .729,40$ & $6.462 .575,00$ \\
\hline Total & $12.406 .774,10$ & $13.588 .797,30$ & $11.028 .403,70$ \\
\hline Keterangan : *: Sementara **: Sangat Sementara $* * *$ : Sangat Sangat Sementara & \\
Sumber : Badan Pusat Statistik, 2018 (diolah PUSDATIN).
\end{tabular}

Sektor pertanian terdiri atas 6 sub sektor, salah satunya adalah sub sektor hortikultura yang terdiri atas tanaman hias tanaman obat, buah-buahan, dan sayuran. Tercatat sebanyak $97,29 \%$ penduduk Indonesia mengkonsumsi sayuran salah satunya adalah tomat (BPS, 2016).

Tomat (Lycopersicon esculentum) merupakan jenis sayuran buah yang tergolong ke dalam tanaman perdu semusim dan famili Solanaceae atau terong-terongan. Pada tahun 2017, Jawa Barat menempati posisi pertama dengan jumlah produksi tomat terbesar di Indonesia yaitu $30,71 \%$ dari total produksi nasional (Statistik Tanaman Sayuran dan Buah-Buahan Semusim Indonesia, 2017).

Salah satu sifat fisik tomat yang mudah rusak menjadikan aktivitas distribusi tomat di pasar tradisional Kota Bogor mengandung berbagai masalah yang berdampak pada margin yang diperoleh. 
Masalah pokok pada kegiatan tataniaga produk pertanian adalah fluktuasi produksi karena bersifat musiman (seasional), relatif panjang (gestation periode), mudah rusak (perishable), dan butuh ruang (Widiastuti, 2013), khususnya komoditas tomat yang mempunyai sifat mudah rusak dan susut.

Menurut Kusumawardhani (2015), aktivitas distribusi menjadi salah satu faktor penyebab munculnya risiko pada produk pertanian.

Hasil survei terdahulu di pasar tradisional Kota Bogor terdapat selisih harga jual yang tinggi terhadap tomat di tingkat retail dengan harga jual di tingkat petani. Tingginya selisih harga tersebut di dalamnya juga terdapat faktor risiko distribusi.

Risiko distribusi menyebabkan meningkatnya biaya tataniaga. Peningkatan biaya tataniaga menyebabkan meningkatnya harga jual di tingkat pelaku yang melakukan distribusi.

Oleh karena itu, diperlukan upaya yang tepat dalam pengelolaan risiko melalui perhitungan proporsi risiko dan alternatif strategi mitigasi untuk mencegah dan meminimlakan dampak negatif yang berpengaruh terhadap perolehan margin pada setiap pelaku tataniaga.

\section{BAHAN DAN METODE}

Penelitian telah dilakukan pada bulan Maret - November 2018 di Pasar tradisional Kota Bogor yang diwakili oleh Pasar Baru Bogor dan Pasar Jambu Dua, Kota Bogor, Jawa Barat.

Pemilihan lokasi dilakukan secara sengaja (purposive) dengan pertimbangan bahwa Pasar Baru Bogor dan Pasar Jambu Dua merupakan 2 pasar tradisional terluas di Kota Bogor yang mendistribusikan sayuran sebagai komoditas utama khususnya tomat, sedangkan lokasi pelaku tataniaga lainnya ditelusuri berdasarkan hasil wawancara dari pelaku tataniaga sebelumnya.

Penentuan responden menggunakan metode purposive sampling dan snowball sampling. Purposive sampling untuk menentukan responden retail 3 orang di Pasar Baru Bogor dan 3 orang di Pasar Jambu Dua yang ditentukan berdasarkan rekomendasi unit PD PPJ dengan pertimbangan responden dapat mewakili pedagang lain untuk informasi yang dibutuhkan. Metode snowball sampling untuk menentukan responden lain yang diruntut berdasarkan hasil wawancara dari pelaku tataniaga sebelumnya.

Responden teridentifikasi terdiri atas 6 orang retail dan 2 orang pedagang besar di pasar retail di Pasar Baru Bogor dan Pasar Jambu Dua, 1 orang pedagang besar di pasar Induk Kemang, 2 orang tengkulak dan 6 orang petani di Desa Pancawati Caringin Kabupaten Bogor dan Desa Pasir Cina Cipanas Kabupaten Cianjur.

Pengumpulan data dilakukan menggunakan teknik wawancara dengan bantuan kuesioner dan observasi lapang. Data dianalisis menggunakan analisis deskriptif dan kuantitatif dengan bantuan microsoft excel 2013. Analisis kuantitatif terdiri atas analisis margin dan analisis risiko.

Analisis Margin Tataniaga

(Nasruddin dan Musyadar, 2015) :

$$
\mathrm{M}=\Sigma \mathrm{c}_{\mathrm{i}}+\sum \pi_{\mathrm{j}}
$$

Keterangan :

$\mathrm{M}=$ Margin tataniaga

$\mathrm{c}_{\mathrm{i}} \quad=$ Biaya tataniaga $(\mathrm{I}=1,2,3, \mathrm{~m})$

$\pi_{\mathrm{j}}=$ Keuntungan yang diperoleh lembaga tataniaga $\mathrm{j}(\mathrm{j}=1,2,3,, \mathrm{n} ;)$

\section{Analisis Risiko}

\section{Enterprise Risk Management (ERM)}

Terdiri atas kegiatan identifikasi risiko, pengukuran dan pemetaan risiko serta tindakakan mitigasi risiko (COSO 2004). Pengukuran risiko menggunakan indikator probabilitas risiko dan indikator dampak risiko. 
Tabel 2 Indikator Probabilitas Risiko

\begin{tabular}{clll}
\hline Skala & \multicolumn{1}{c}{ Skala Probabilitas } & \multicolumn{1}{c}{ Keterangan } & \multicolumn{1}{c}{$\begin{array}{c}\text { Interval Kejadian } \\
\text { dalam Setahun }\end{array}$} \\
\hline 1 & $\begin{array}{l}\text { Sangat Rendah } \\
\text { (Improbable) }\end{array}$ & $\begin{array}{l}\text { Hampir tidak mungkin } \\
\text { terjadi }\end{array}$ & $<5 \mathrm{kali}$ \\
2 & Rendah (Remote) & Kadang terjadi & $5-10 \mathrm{kali}$ \\
3 & Sedang (Occasional) & Mungkin terjadi & $11-20 \mathrm{kali}$ \\
4 & Tinggi (Probable) & Sangat mungkin terjadi & $20-30 \mathrm{ali}$ \\
5 & Sangat Tinggi & Hampir pasti terjadi & $>30 \mathrm{kali}$ \\
\hline Sumber $:$ Godfrey (1996) & &
\end{tabular}

Tabel 3 Indikator Dampak Risiko

\begin{tabular}{cll}
\hline Skala & \multicolumn{1}{c}{ Skala Probabilitas } & \multicolumn{1}{c}{ Keterangan } \\
\hline 1 & Sangat Rendah (Neglible) & Tidak menimbulkan masalah berarti. \\
2 & Rendah (Marginal) & $\begin{array}{l}\text { Menimbulkan masalah kecil yang diatasi dengan } \\
\text { pengelolaan rutin. } \\
\text { Mencegah setiap pelaku tataniaga dalam mencapai } \\
\text { tujuan pada periode tertentu. }\end{array}$ \\
3 & Sedang (Serious) & $\begin{array}{l}\text { Mengakibatkan pelaku tataniaga tidak dapat mencapai } \\
\text { tujuannya dalam jangka panjang. }\end{array}$ \\
4 & Tinggi (Critical) & Mengakibatkan kebangkrutan pada perusahaan. \\
5 & $\begin{array}{l}\text { Sangat Tinggi } \\
\text { (Catasthropic) }\end{array}$ & \\
\hline
\end{tabular}

Sumber : Godfrey (1996)

Selanjutnya dilakukan pengukuran nilai risiko menggunakan rumus :

Keterangan :

$$
\mathrm{R}=\mathrm{P} \times \mathrm{I}
$$

$\mathrm{R}$ : Tingkat Risiko
P : Probabilitas risiko yang terjadi

I : Dampak risiko yang terjadi

Selanjutnya membuat peta risiko berdasarkan nilai risiko yang diperoleh.

Tabel 4 Peta Risiko

\begin{tabular}{|c|c|c|c|c|c|}
\hline & $\begin{array}{c}\text { Sangat Tinggi } \\
5\end{array}$ & $\begin{array}{c}\text { Tinggi } \\
4\end{array}$ & $\begin{array}{c}\text { Sedang } \\
3 \\
\end{array}$ & $\begin{array}{c}\text { Rendah } \\
2 \\
\end{array}$ & $\begin{array}{c}\text { Sangat Rendah } \\
1\end{array}$ \\
\hline $\begin{array}{l}\text { Frequent } \\
5\end{array}$ & $\begin{array}{c}25 \\
\text { Unacceptable }\end{array}$ & $\begin{array}{c}20 \\
\text { Unacceptable }\end{array}$ & $\begin{array}{c}15 \\
\text { Unacceptable }\end{array}$ & $\begin{array}{c}10 \\
\text { Undesirable }\end{array}$ & $\begin{array}{c}5 \\
\text { Undesirable }\end{array}$ \\
\hline $\begin{array}{c}\text { Tinggi } \\
4 \\
\end{array}$ & $\begin{array}{c}20 \\
\text { Unacceptable }\end{array}$ & $\begin{array}{c}16 \\
\text { Unacceptable }\end{array}$ & $\begin{array}{c}12 \\
\text { Undesirable }\end{array}$ & $\begin{array}{c}8 \\
\text { Undesirable }\end{array}$ & $\begin{array}{c}4 \\
\text { Acceptable }\end{array}$ \\
\hline $\begin{array}{c}\text { Sedang } \\
3\end{array}$ & $\begin{array}{c}15 \\
\text { Unacceptable }\end{array}$ & $\begin{array}{c}12 \\
\text { Undesirable }\end{array}$ & $\begin{array}{c}9 \\
\text { Undesirable }\end{array}$ & $\begin{array}{c}6 \\
\text { Undesirable }\end{array}$ & $\begin{array}{c}3 \\
\text { Acceptable }\end{array}$ \\
\hline $\begin{array}{c}\text { Rendah } \\
2\end{array}$ & $\begin{array}{c}10 \\
\text { Undesirable }\end{array}$ & $\begin{array}{c}8 \\
\text { Undesirable }\end{array}$ & $\begin{array}{c}6 \\
\text { Undesirable }\end{array}$ & $\begin{array}{c}4 \\
\text { Acceptable }\end{array}$ & $\begin{array}{c}2 \\
\text { Sangat Rendah }\end{array}$ \\
\hline $\begin{array}{c}\text { Sangat } \\
\text { Rendah } \\
1 \\
\end{array}$ & $\begin{array}{c}5 \\
\text { Undesirable }\end{array}$ & $\begin{array}{c}4 \\
\text { Acceptable }\end{array}$ & $\begin{array}{c}3 \\
\text { Acceptable }\end{array}$ & $\begin{array}{c}2 \\
\text { Sangat } \\
\text { Rendah }\end{array}$ & $\begin{array}{c}1 \\
\text { Sangat Rendah }\end{array}$ \\
\hline
\end{tabular}

Sumber : Godfrey (1996)

\section{Proporsi Risiko}

$$
\text { Proporsi Risiko }=\frac{X_{\mathrm{i}}}{\Sigma X} \times 100 \%
$$

Keterangan :

selama proses distribusi dari retail sampai ke petani.

$X_{\mathrm{i}}$ : Nilai risiko yang ditanggung oleh pelaku tataniaga ke-i

$\Sigma X:$ Jumlah total risiko yang terjadi 


\section{HASIL DAN PEMBAHASAN}

\section{Karakteristik Responden}

Pelaku tataniaga tomat didominasi oleh kaum laki-laki yang berusia 30-39 tahun dengan jumlah tanggungan keluarga antara 3-5 orang dan mayoritas responden hanya mengenyam pendidikan hingga tingkat Sekolah Dasar (SD). Mayoritas responden tomat sudah memiliki pengalaman usaha dibidang usaha tomat sekitar 11-20 tahun.

\section{Margin Tataniaga}

Margin tataniaga yang teridentifikasi terdapat 3 saluran yaitu saluran (1) retail pedagang besar di pasar retail - pedagang besar di pasar induk - tengkulak - petani (2) retail - pedagang besar di pasar induk petani (3) retail - pedagang besar di pasar retail - tengkulak - petani.

Pada saluran tataniaga 1 , persentase margin di tingkat retail sebesar $25,75 \%$ (Rp. 1.792), di tingkat pedagang besar di pasar retail sebesar 19,16\% (Rp. 1.333), dan di tingkat pedagang besar di pasar induk sebesar 31,14\% (Rp. 1.667).

Pada saluran tataniaga 2, persentase margin di tingkat retail sebesar 70,86\% (Rp. 5.269), dan di tingkat pedagang besar di pasar induk sebesar 29,14\% (Rp. 2.167).

Pada saluran tataniaga 3, persentase margin di tingkat retail sebesar 49,32\% (Rp. 4.000), di tingkat pedagang besar di pasar retail sebesar 20,54\% (Rp. 1.666), dan di tingkat tengkulak sebesar $30,14 \%$ (Rp. 2.445).

\section{Analisis Risiko Distribusi Tomat dengan Metode Enterprise Risk Management (ERM)}

\section{ERM 1. Internal Environment (Identifikasi Pasar Tradisional Kota Bogor)}

Pasar tradisional Kota Bogor terdiri atas 12 pasar yang tersebar di sekitar Kota Bogor dan dikelola oleh Pemerintah Kota Bogor bersama dengan pihak swasta (PD Pasar Pakuan Jaya).
Pasar Baru Bogor dan Pasar Jambu menjadi 2 pasar tradisional terluas di Kota Bogor yang menjual sayuran sebagai komoditas utama khususnya tomat. Pasar Baru Bogor berdiri pada abad ke-17, sedangkan Pasar Jambu Dua berdiri pada tahun 2000 .

\section{ERM 2. Objective Setting}

Pelaku tataniaga tomat yang menjadi responden di pasar tradisional Kota Bogor terdapat sebanyak 17 orang dan seluruh pelaku belum memiliki visi dan misi dalam kegiatan usaha tomat yang telah dijalankannya selama ini.

\section{ERM 3. Event Identivication} (Identifikasi Risiko Distribusi)

Pada beberapa kegiatan distribusi yang dilakukan oleh 17 orang pelaku tataniaga, teridentifikasi 3 jenis risiko yaitu susut bobot, rusak fisik dan tidak terjual. Susut bobot merupakan berkurangnya bobot pada tomat, rusak fisik merupakan berkurangnya tampilan fisik pada tomat dan tidak terjual merupakan sisa tomat yang tidak terjual habis.

Susut bobot terjadi di tingkat retail disebabkan karena paparan sinar matahari secara langsung yang menyebabkan penguapan kadar air pada tomat (respirasi), di tingkat pedagang besar di pasar retail, pedagang besar di pasar induk, dan tengkulak saat pengiriman dari kebun ke Pasar Induk Kemang atau ke pasar tradisional di Kota Bogor, serta di tingkat petani saat sortasi.

Risiko rusak fisik teridentifikasi salah satunya berupa tomat overripe (sudah terlewat matang), tomat berlubang akibat serangan hama ulat dan penyakit, serta rusak akibat proses pemetian dengan kapasitas berlebihan yang terjadi di tingkat retail saat sortasi, di tingkat pedagang besar di pasar retail, di tingkat pedagang besar di pasar induk, dan di tingkat petani.

Risiko tidak terjual teridentifikasi terjadi di tingkat retail, di tingkat pedagang besar di pasar retail, dan di tingkat pedagang besar di pasar induk saat 
proses menjual dagangan di kios/los yang disebabkan oleh ketersediaan tomat yang berlebih dan kerusakan fisik pada tomat.

\section{ERM 4. Risk Assesment}

(Pengukuran dan Pemetaan Risiko)

Penilaian risiko distribusi pada pelaku tataniaga tomat di pasar tradisional Kota Bogor dilakukan melalui kegiatan wawancara dengan bantuan kuesioner. Berdasarkan hasil wawancara, risiko susut bobot, rusak fisik, dan tidak terjual pada setiap pelaku tataniaga dalam 2 siklus distribusi selama 1 tahun hanya terjadi sebanyak 2 kali, kecuali pada petani terjadi sebanyak 28 kali sesuai dengan siklus panen dalam 1 tahun.

Setiap risiko menimbulkan dampak yang sama bagi pelaku tataniaga, yaitu kerugian dan terhambatnya perputaran modal. Selanjutnya, dilakukan pembobotan skor terhadap risiko yang terjadi dan dampak yang diterima oleh pelaku tataniaga untuk mengetahui tingkat keparahan risiko pada peta risiko.

Berdasarkan hasil pengukuran risiko, risiko susut bobot dan rusak fisik saat sortasi di tingkat petani menghasilkan skor
8 yang tergolong ke dalam tingkat risiko undesirable (risiko tersebut harus diwaspadai karena berpengaruh signifikan terhadap usaha yang dilakukannya).

Susut bobot saat pengiriman dan menjual dagangan di tingkat retail, saat pengiriman dan menjual dagangan di tingkat pedagang besar pasar retail, saat menjual dagangan di tingkat pedagang besar pasar induk, serta saat pengiriman di tingkat tengkulak menghasilkan skor 2-4 yang tergolong ke dalam tingkat risiko acceptable.

Rusak fisik saat sortasi di tingkat retail, di tingkat pedagang besar di pasar retail, di tingkat pedagang besar di pasar induk, dan saat menjual dagangan di tingkat retail, serta risiko tidak terjual saat menjual dagangan di tingkat retail dan di tingkat pedagang besar di pasar induk menghasilkan skor 4 yang tergolong ke dalam tingkat risiko acceptable (risiko dapat diterima karena memiliki dampak yang masih bisa diatasi).

Tingkatan risiko berdasarkan skor risiko dan dampaknya dapat dilihat pada Gambar 1.

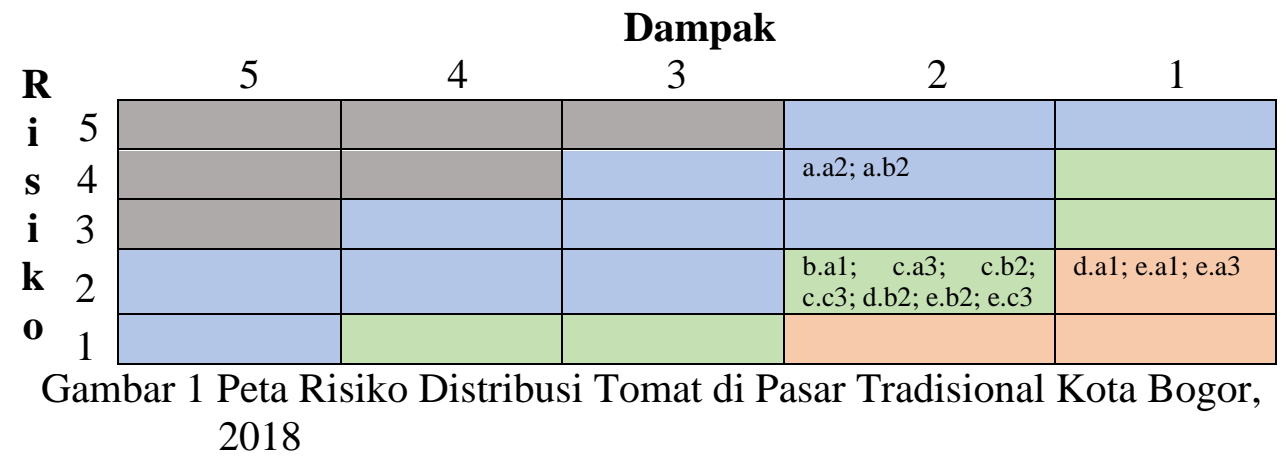

Keterangan :

Unacceptable : Tinggi
Acceptable : Rendah

Berdasarkan peta risiko pada Gambar 1, menunjukkan bahwa sebagian besar risiko distribusi terdapat pada kolom hijau dengan skor total 4 (skor dampak 2 dan skor risiko 2) yang terdiri atas risiko susut bobot saat pengiriman di tingkat
Undesirable : Sedang

Negligible : Sangat Rendah

tengkulak (b.a1), susut bobot saat menjual dagangan (c.a3).

Rusak fisik saat sortasi (c.b2) serta tidak terjual saat menjual dagangan di tingkat pedagang besar di pasar induk (c.c3), rusak fisik saat sortasi di tingkat pedagang besar di pasar retail (d.b2), 
rusak fisik saat sortasi (e.b2) dan tidak terjual saat menjual dagangan di tingkat retail. (e.c3).

\section{ERM 5 : Risk Response (Tindakan Mitigasi Risiko)}

Tindakan mitigasi risiko terdiri atas 5 jenis yaitu, (1) respon menerima (accept), (2) mengurangi (reduce), (3) mencegah (prevent), dan (4) berbagi (transfer). Tindakan mitigasi di tingkat retail, di tingkat pedagang besar di pasar retail, di tingkat pedagang besar di pasar induk, dan di tingkat tengkulak dapat dilakukan dengan cara menerima efek dari risiko berupa kerugian dan mengurangi risiko, sedangkan tindakan mitigasi di tingkat petani dilakukan dengan cara mencegah atau mengurangi risiko yang terjadi.

\section{ERM 6: Control Activities}

Bentuk pengendalian yang dapat dilakukan oleh setiap pelaku tataniaga tomat berupa (1) keikutsertaan dalam kegiatan pelatihan dan penyuluhan budidaya tanaman hortikultura dan penanganan pascapanen khususnya pada produk hortikultura, (2) serta melakukan pencatatan hasil usaha yang dimulai dari biaya-biaya, kerugian, dan keuntungan yang diperoleh secara terperinci. Pencatatan hasil usaha dilakukan agar setiap pelaku tataniaga dapat mengetahui sejauh mana perkembangan usahanya, sehingga dapat menganalisis jenis risiko yang mempengaruhi perkembangan usahanya dan tindakan alternatif yang perlu dilakukan untuk mengendalikan risiko tersebut agar tidak menghambat perkembangan usaha yang dijalankan.

\section{ERM 7 : Information and Communication}

Komunikasi yang efektif antar pelaku tataniaga dapat menghasilkan informasi yang relevan seperti informasi harga, kualitas, jumlah pasokan dan informasi lain khsususnya informasi mengenai risiko distribusi untuk mendukung penerapan tindakan mitigasi yang tepat bagi setiap risiko pada pelaku tataniaga.

Perolehan informasi yang relevan dapat dilakukan dengan mengadakan pertemuan rutin atau diskusi oleh setiap pelaku melalui media sosial atau telepon mengenai berbagai masalah dalam usaha khususnya dalam kegiatan pendistribusian tomat dan solusi yang dapat dilakukan oleh setiap pelaku yang terlibat.

\section{ERM 8 : Monitoring}

Kegiatan monitoring dapat dilakukan oleh pihak yang dianggap telah ahli dalam bidang penanganan pascapanen dan pemasaran produk hortikultura kepada setiap pelaku tataniaga, khususnya pada kegiatan pendistribusian hasil panen dengan baik dan benar untuk menghindari berbagai risiko yang mungkin terjadi.

\section{Proporsi Risiko Distribusi Tomat di Pasar Tradisional Kota Bogor, 2018}

Berdasarkan jumlah tomat yang diusahakan oleh masing-masing pelaku tataniaga, pada saluran tataniaga 1 dan 2 persentase risiko terbesar terdapat di tingkat retail yaitu $9,84 \%$ dan $8,50 \%$, pada saluran tataniaga 3 terdapat di tingkat tengkulak yaitu $5 \%$, sedangkan persentase risiko terkecil pada saluran tataniaga 1 terdapat di tingkat tengkulak yaitu $0,50 \%$, pada saluran tataniaga 2 dan 3 terdapat di tingkat petani yaitu $0,68 \%$ dan $1,55 \%$.

Berdasarkan jumlah tomat yang diusakan oleh seluruh pelaku tataniaga, pada saluran tataniaga 1 dan 2 persentase risiko terbesar terdapat di tingkat retail yaitu $45,01 \%$ dan $70,72 \%$, pada saluran tataniaga 3 terdapat di tingkat tengkulak yaitu $36,90 \%$, sedangkan persentase risiko terkecil pada saluran tataniaga 1 terdapat di tingkat tengkulak yaitu $2,29 \%$, pada saluran tataniaga 2 dan 3 terdapat di tingkat petani yaitu $5,66 \%$ dan $11,44 \%$.

\section{Persentase Margin Tomat di Pasar Tradisional Kota Bogor, 2018}

Pada saluran tataniaga 1, persentase margin terkecil terdapat di tingkat pedagang besar di pasar retail sebesar 
19,16\% (Rp. 1.333/kg), margin terbesar terdapat di tingkat pedagang besar di pasar induk sebesar 31,14\% (Rp. 2.167/kg).

Pada saluran tataniaga 2, persentase margin terkecil terdapat di tingkat pedagang besar di pasar induk sebesar $29,14 \%$ (Rp. 2.167/kg), margin terbesar terdapat di tingkat retail sebesar 70,86\% (Rp. 5.269/kg).

Pada saluran tataniaga 3 , persentase margin terkecil terdapat di tingkat pedagang besar di pasar retail sebesar $20,54 \%$ (Rp. $1.666 / \mathrm{kg}$ ), margin terbesar terdapat di tingkat retail sebesar 49,32\% (Rp. 4.000/kg).

\section{Perbandingan Persentase Margin dengan Risiko Distribusi Tomat di Pasar Tradisional Kota Bogor, 2018}

Berdasarkan perbandingan antara persentase margin yang diperoleh dengan risiko yang ditanggung oleh pelaku tataniaga, pembagian yang proporsional hanya terdapat pada saluran tataniaga 2 , karena persentase margin terbesar dan risiko terbesar sama-sama terdapat di tingkat retail yaitu margin $70,86 \%$ dan risiko $70,72 \%$.

Pembagian antara margin dan risiko pada saluran tataniaga 1 dan 3 belum proporsional. Pada saluran tataniaga 1, hal tersebut terjadi karena persentase margin terbesar berada di tingkat pedagang besar di pasar induk yaitu $31,14 \%$, sedangkan persentase risiko terbesar ditanggung oleh retail sebesar $45,01 \%$ dari total risiko seluruh pelaku tataniaga pada saluran tataniaga 1, atau sebesar $9,84 \%$ jika dipersentasekan berdasarkan jumlah tomat yang hanya diusahakan oleh retail yang terdiri atas susut bobot $0,59 \%$, rusak fisik $2,80 \%$, dan tidak terjual $6,45 \%$.

Pada saluran tataniaga 3 , pembagian margin dan risiko tidak proporsional karena persentase margin terbesar berada di tingkat retail sebesar 49,32\%, sedangkan persentase risiko terbesar ditanggung oleh tengkulak sebesar 36,90\% dari total risiko seluruh pelaku tataniaga pada saluran tataniaga 3, atau $5,00 \%$ yang hanya merupakan risiko susut bobot jika dipersentasekan berdasarkan jumlah tomat yang hanya diusahakan oleh tengkulak.

\section{KESIMPULAN DAN IMPLIKASI KEBIJAKAN}

\section{Kesimpulan}

Margin terbesar terdapat di tingkat retail pada saluran tataniaga 2 , sedangkan margin terkecil terdapat di tingkat pedagang besar di pasar retail pada saluran tataniaga 1.

Risiko terbesar terdapat di tingkat retail pada saluran tataniaga 2 , sedangkan risiko terkecil terdapat di tingkat tengkulak pada saluran tataniaga 1. Proporsi antara besarnya pembagian margin dengan risiko terdapat di tingkat retail pada saluran tataniaga 2.

Pemetaan risiko berdasarkan besarnya dampak bagi pelaku tataniaga adalah risiko yang harus diwaspadai oleh pelaku tataniaga terdapat pada (1) susut bobot dan (2) rusak fisik saat sortasi di tingkat petani. Risiko yang jarang terjadi terdapat pada (1) susut bobot saat pengiriman di tingkat pedagang besar di pasar retail, dan di tingkat retail, serta saat menjual dagangan di tingkat retail.

Risiko yang sering terjadi, namun memiliki dampak yang relatif kecil terdapat pada (1) susut bobot saat pengiriman di tingkat tengkulak dan di tingkat pedagang besar di pasar retail, serta saat menjual dagangan di tingkat pedagang besar di pasar induk, (2) rusak fisik saat sortasi di tingkat pedagang besar di pasar induk, di tingkat pedagang besar di pasar retail, dan di tingkat retail, (3) tidak terjual saat menjual dagangan di tingkat pedagang besar di pasar induk dan di tingkat retail.

Tindakan mitigasi susut bobot dilakukan di tingkat petani dan di tingkat tengkulak. Tindakan mitigasi rusak fisik di tingkat petani, di tingkat pedagang besar di pasar induk, di tingkat pedagang besar di pasar retail, dan di tingkat retail. Tindakan mitigasi tidak terjual di tingkat pedagang besar di pasar induk dan di tingkat retail. 


\section{Implikasi Kebijakan}

Saluran tataniaga 2 sebaiknya mengaplikasikan aktivitas tataniaga sesuai dengan rantai tataniaga yang sudah efisien agar pembagian margin dapat merata melalui pengelolaan risiko dengan cara membuat gudang khusus sortasi untuk petani, melakukan prediksi trend permintaan pasar oleh pedagang besar di pasar induk dan retail.

Tindakan mitigasi susut bobot di tingkat petani dapat dilakukan dengan cara pembuatan gudang sortasi, di tingkat tengkulak dengan cara penggunaan terpal sebagai atap pada tomat. Rusak fisik di tingkat petani dilakukan dengan cara pemberian pupuk dan pestisida yang sesuai dengan kebutuhan tanaman.

Di tingkat pedagang besar di pasar induk, di tingkat pedagang besar di pasar retail, dan di tingkat retail tindakan mitigasi dilakukan dengan cara membuat perjanjian jumlah penaggungan kerusakan tomat dan menugaskan tenaga kerja untuk mengawasi proses sortasi dan pemetian. Tidak terjual di tingkat pedagang besar di pasar induk dan di tingkat retail dilakukan dengan cara membuat prediksi trend permintaan pasar.

\section{Daftar Pustaka}

Badan Pusat Statistik, 2018. Basis Data Produk Domestik Bruto (PDB). Kementerian Pertanian Republik Indonesia. Pertanian.go.id. Diakses 17 November 2018.

Badan Pusat Statistik, 2017. Konsumsi Buah dan Sayur Susenas Maret 2016. gizi.depkes.go.id. Diakses 12 Desember 2018.

Statistik Tanaman Sayuran dan BuahBuahan Semusim Indonesia. 2017. Badan Pusat Statistik. www.bps.go.id. Diakses 29 Januari 2019.

Badan Pusat Statistik Kota Bogor. 2017. Kota Bogor dalam Angka 2017. Badan Pusat Statistik Kota Bogor. Kota
http://bappeda.kotaBogor.go.id.

Diakses 21 Februari 2018.

Widiastuti N, Mohd H. 2013. Saluran dan Margin Pemasaran Jagung di Kabupaten Grobogan. SEPA. Vol 9 (2) : 233. Diakses 26 April 2018.

Kusumawardhani Y, Muhammad S, Anggraini S. 2015. Model Optimasi dan Manajemen Risiko pada Saluran Distribusi Rantai Pasok Sayuran Dataran Tinggi Wilayah Sumatera. Jurnal MPI. Vol. 10 (1) : 34. Diakses 4 Mei 2018.

Nasruddin W, Ahmad M. 2015. Tataniaga Pertanian. Universitas Terbuka. Tangerang Selatan, 1.4-6.39.

The Commiitee of Sponsoring Organizations (COSO) of The Treadway Commision. 2004. Enterprise Risk ManagementIntegrated Framework. www.theii.org. Diakses 24 September 2018. 